\title{
DEVELOPMENT OF ENRICHED CUPCAKES AND COOKIES WITH ORANGE- FLESHED SWEET POTATO (Ipomeabatatas L.): SENSORY AND NUTRITIONAL EVALUATION
}

\author{
*Gisèle Ahou Yah KOUA ${ }^{1}$, Konan Evrad Brice DIBI ${ }^{2}$, \\ Edwige Essoma AKOA ${ }^{1}$, Sébastien NIAMKE ${ }^{1}$ \\ ${ }^{I}$ Faculty of Biosciences, Félix Houphouët-Boigny University, \\ 22 BP 582 Abidjan 22, Abidjan, Côte d'Ivoire, kouayahgisele@ yahoo.fr, \\ ${ }^{2}$ National Agronomic Research Center (CNRA), Bouaké, Côte d'Ivoire, \\ *Corresponding author \\ Received $26^{\text {th }}$ March 2021, accepted $29^{\text {th }}$ June 2021
}

\begin{abstract}
In developing countries especially in Côte d'Ivoire child malnutrition is a major burden. This malnutrition is often associated with poor nutritional composition of the complementary foods introduced during the weaning period. The purpose of this study was to assess nutritional, microbiological, and sensory properties of cupcakes and cookies supplemented with orange-fleshed sweet potato (OFSP). The proximate and microbiological analysis of enriched products was performed using analytical standard methods. Sensory evaluation of formulated cupcakes and cookies was based on nine-point hedonic scales. Proximate composition showed significant improvements in the contents of ash $(1.02 \pm 0.06-1.98 \pm 0.03 \mathrm{~g} / 100 \mathrm{~g} \mathrm{dw})$, fiber $(5.39 \pm 0.13-7.64 \pm 0.47 \mathrm{~g} / 100 \mathrm{~g} \mathrm{dw})$, and provitamin A (1031 - $4641 \mu \mathrm{g} / 100 \mathrm{~g} d w)$ of enriched cupcakes and cookies compared to control. Based on moderate daily consumption of two pieces of OFSP composite cupcakes (60g/piece) and cookies (44g/piece), children aged 1 to 3 years may cover at least 42 and $85 \%$ of their RDA for vitamin A, respectively. The microbial analysis indicated showed that enriched OFSP cupcakes and cookies were of acceptable microbiological quality. In addition, the enriched OFSP cupcakes and cookies were accepted and liked by the consumers excepted those containing 50\% OFSP flour. Thus, cupcakes and cookies formulated with $35 \%$ OFSP flour can serve as a valuable vehicle for improving the nutritional status of young children.
\end{abstract}

Keywords: cupcakes, cookies, OFSP, nutritional value, sensory acceptance.

\section{Introduction}

Malnutrition continues to be a major public health issue in the world, especially in developing countries, due to insufficient quality and quantity food intake [1]. It affects many people in sub-Saharan and causes death and morbidity in young children under 5 years [2]. Despite progressive health system improvement high malnutrition rates in Côte d'Ivoire for children under 5 years old, constitutes a significant burden regarding economic and social development [3]. Like other countries of sub-Saharan Africa, the major contributing factors to child malnutrition in Côte d'Ivoire are protein-energy and micronutrient deficiencies. Micronutrient deficiency also called "hidden hunger" is often related to the nutritional composition of complementary foods introduced in the weaning period [5]. Indeed, these complementary foods are mostly composed of starchy foods resulting in deficiencies of key nutrients such as 
proteins, iron, zinc, calcium, vitamin $\mathrm{A}$, and vitamin $\mathrm{C}$ [6].

Numerous researches suggest that the use of local crops which are rich sources of micronutrients in food proven to be a viable and sustainable approach in tackling all forms of malnutrition in addition to promoting food security in long term [7]. Currently, reports abound on the positive effects of orange-fleshed sweet potato (OFSP) on the well-being of people of some African countries like Kenya, Uganda, Nigeria, and Mozambique [8], [9]. Indeed, Orange-fleshed sweet potato (OFSP) is well known as a staple food that has several nutritional advantages with relatively low cost. It makes an important contribution to energy and micronutrient requirements in rural and low-income communities [10]. In addition, OFSP flour is considered as an excellent source of $\beta$ carotene (provitamin A), energy and minerals ( $\mathrm{Ca}, \mathrm{P}, \mathrm{Fe}, \mathrm{Zn}$, and $\mathrm{K})$. It contribute also to add natural sweetness, color, flavor, and dietary fiber to processed foods products[8], [11]. Thus, adding OFSP into wheat flour may be a valuable strategy for provitamin A fortification of baked products such as biscuits, cakes, cookies, considered as snack foods [12], [13]. Primarily formulated by using refined wheat flour; snack foods represent an important part of human diet, generally consumed between meals. The snack foods are mainly consumed by young children and adolescents can help achieve an individual's RDA within a day [14].

In recent years, substitution of wheat flour with non glutenflours from secondary crops such as cassava, cocoyam, sweet potato, maize, rice, millet, sorghum and soybean for bakery products processing has gained prominence in low-income countries[15], [16]. However, in Côte d'Ivoire, little researches have mentioned the use of flours from these secondary crops, especially the new varieties of
OFSP for bakery foods (cupcakes and cookies) preparation. Indeed, the utilization of OFSP cultivars is limited to water or steam cooking for traditional meals preparation. Thus, the purpose of this study is to determine the nutritional value, microbial and sensory properties of two snack foods (cupcakes and cookies) developed by using composite flour from three new cultivars of OFSP.

\section{Matherials and methods}

\subsection{Samples preparation}

The OFSP flours were obtained from roots of OFSP cultivars called "Irene" (V1), "Kabode" (V4) and "Covington" (V5) harvested in experimental farm located in the North (two localities: Korhogo and Boundiali) and North-East (two localities: Bondoukou and Nassian) regions of Côte d'Ivoire. Briefly, OFSP roots were peeled in thin slices and dried at $50^{\circ} \mathrm{C}$ in ventilated oven for $18 \mathrm{~h}$. Dried OFSP chips were milled into flour. The other ingredients such as wheat flour and baked products ingredients (butter, sugar, salt, egg, milk, and baking powder) were purchased from a shopping mall (Abidjan mall) in Abidjan (Côte d'Ivoire).

\subsection{Flours and bakery products formulation}

For this study, different ratios of composite flour make from wheat flour and OFSP flour were used: 100:0 (control), 85:15, 75:25, 65:35, and 50:50 (w/w). Cupcakes were prepared by mixing $100 \mathrm{~g}$ of composite flour, butter (50 g), sugar $(25 \mathrm{~g})$, milk powder $(10 \mathrm{~g})$, baking powder $(1 \mathrm{~g})$, water $(25 \mathrm{~mL})$, and pinch of salt. The formulation for cookies preparation was: composite flour (100 g), butter (75g), sugar $(85 \mathrm{~g})$, eggs $(10 \mathrm{~g})$, whole milk $(15 \mathrm{~mL})$ and baking powder $(1 \mathrm{~g})$. The resulting dough was baked in an oven at $180^{\circ} \mathrm{C}$ for $5 \mathrm{~min}$. The cupcakes and cookies were 
immediately cooled and used for further analyses. All the baked products were vacuum-sealed in opaque zip-lock bags and stored at $4{ }^{\circ} \mathrm{C}$ until required.

\subsection{Proximate composition evaluation}

The methods described in the Official Methods of Analysis of AOAC International were used to determine the contents of moisture, ash and proteins [17]. Crude fat contents were evaluated by Soxhlet extraction described by [18]. Total fiber content was determined by the method described by [19]. Carbohydrates were calculated by difference while energy value was determined using factors determined described by [20].

Carotenoid content in the baked products was evaluated according to the method described by [21]. Powdered samples (1 g) were mixed with $5 \mathrm{~mL}$ ethanol containing butylated hydroxytoluene $(0.1 \%, \mathrm{w} / \mathrm{v})$ and heated in water bath at $85^{\circ} \mathrm{C}$ for $5 \mathrm{~min}$. Then, $400 \mu \mathrm{L} \mathrm{KOH}$ in water $(80 \%$, w/v) was added for saponification and the suspension was mixed using a vortex for $20 \mathrm{~s}$ and heated again in a water bath at $85^{\circ} \mathrm{C}$ for $5 \mathrm{~min}$. The tubes containing the mixture reaction were placed in ice after introducing $3 \mathrm{~mL}$ distillated water and carotenoids were extracted two times with $4 \mathrm{~mL}$ of hexane. The suspension was centrifuged at $12000 \mathrm{rpm}$ for $10 \mathrm{~min}$ and the supernatants were collected in a flask. The absorbance of combined extracts was measured at $450 \mathrm{~nm}$ using spectrophotometer (Thermo Scientific ${ }^{\mathrm{TM}}$ Evolution $201 \quad$ UV-Visible spectrophotometer, France) and was used to quantify total carotenoids with a calibration curve of $\beta$-carotene as standard. The $\beta$-carotene values were used to calculate vitamin A contribution contributed to the diet, expressed as retinol equivalents (RAE), where $12 \mu \mathrm{g} \beta$ carotene is converted to $1 \mu \mathrm{g} \mathrm{RAE}$ [22].

\subsection{Microbiology evaluation}

Microbiology quality of OFSP cookies and cupcakes samples was analyzed using standard methods described by International organization standardization (ISO). Briefly, $10 \mathrm{~g}$ of each OFSP baked products were taken aseptically and homogenized in $90 \mathrm{~mL}$ tryptone salt in stomacher, and serial decimal dilutions $\left(10^{-1}\right.$ to $\left.10^{-5}\right)$ were performed. One milliliter $(1 \mathrm{~mL})$ of each dilution was poured plated in sterile Petri dishes. The total viable bacterial counts (TVC) were carried out according to method [23], while the total mold and yeast count was determined by [24] method. The procedure [25] was used to count anaerobic sulfatereducing bacteria (ASB) while total coliform bacteria count was carried with method[26]. Detection of Staphylococcusaureus and Salmonella strains were done according to methods[27] and [28], respectively. The results of microorganisms count were expressed as $\log \mathrm{CFU} / \mathrm{g}$.

\subsection{Sensory evaluation}

Sensory evaluation of OFSP cupcakes and cookies was carried out using attributes including appearance, color, taste, aroma, texture, mouthfeel, and overall acceptability. A nine-point hedonic scale (1-dislike very much and 9-like very much) was used to evaluate for abovementioned sensory attributes [29]. The evaluation was undertaken by a panel of thirty mothers including breastfeeding mothers and non-breastfeeding mothers who have fed babies before. The samples were presented to each panelist in triplicates and average scores were reported. 


\subsection{Statistical analysis}

All experiments were performed with three replications. The statistical analysis of collected data was performed by one-way analysis of variance (ANOVA) using Statistica software version 7.1 to determine differences among the treatments. Significant differences among means of treatments were obtained by Duncan's multiple rank test at $\mathrm{p}<0.05$.

\section{Results and discussion}

\subsection{Proximate composition of the compsite OFSP flour baked products}

As shown in Tables 1 and 2, there was a significant $(p<0.05)$ difference in the nutritional properties of the enriched OFSP cupcakes and cookies. The results revealed that fat, proteins, carbohydrates content, and energy value decreased as level of OFSP flour increased. Contrary to this moisture, ash, fiber, and $\beta$-carotene contents increased as proportion of OFSP flour increased in the formulation. The highest moisture content was found for cupcakes and cookies contained 50\% OFSP flour. The reported results were similar to the findings of [30]. The increase of moisture content in the bakery products might be attributed to the higher water absorption capacity of the composite flour compared to wheat flour [31], [32]. However, lower moisture content of baked products is required for long time shelf life according to the report of [33]. Based on the relatively high moisture content $(14.18 \pm 0.04$ to $16.79 \pm 0.04 \%)$, cupcakes could be considered as intermediatemoisture foods characterized by soft and tender eating properties[34]. Moreover, the rapid consumption of these cupcakes is recommended to avoid microbial spoilage limiting their shelf life.

Fiber content in blended products is ranging from $5.38 \pm 0.16$ to $7.64 \pm 0.0 .26 \%$ and $5.39 \pm 0.13$ to $7.70 \pm 0.20 \%$ for cupcake and cookies, respectively. The crude fiber contents of baked products were significantly $(\mathrm{p}<0.05)$ higher than that of the control $(1.52 \pm 0.22$ and $2.51 \pm 0.12$ $\mathrm{g} / 100 \mathrm{~g} \mathrm{dw})$. These trends could be attributed to the high content of fiber of OFSP flour than wheat as mentioned by [35]. Similar result was reported by [36], [37] in other baked products. These results highlighted that consumption of one piece of enriched OFSP cupcake (54 g/piece) or two pieces of enriched OFSP cookies (44 $\mathrm{g} /$ piece) could contribute to $24.82-35.25 \%$ and $36.49-52.10 \%$ of fiber's recommended dietary allowance (RDA) for preschool children (1-3 years) that is estimated to 13 g/day. According to the reports of [38], foods containing more fiber have beneficial effects on the reduction of blood cholesterol and risk of colon cancer. Moreover, dietary fiber enhances the rheological properties of doughs and overall acceptability of the resulting baked products [39].

The ash content of composite flour cupcake $(1.64 \pm 0.10$ to $1.98 \pm 0.03 \%)$ and cookies $(1.02 \pm 0.06$ to $1.71 \pm 0.05 \%)$ was significantly $(\mathrm{p}<0.05)$ higher as compared to those of the controls. Results showed that as the OFSP flour proportion increases in the composite flours the ash contents of the blend increases. Thus, the highest ash content was observed for composite flour cupcake $(1.98 \pm 0.03 \%)$ and cookies $(1.71 \pm 0.05 \%)$ made from $50 \%$ of OFSP flour and the lowest was for the controls. The same trend was recorded in the ash content of the composite cakes and cookies made with wheat-OFSP flour reported by [40], [41]. It can be concluded that substitution of wheat flour with OFSP flour in the blends could enhance the mineral intake of consumers of the final composite products developed for proper growth and development especially for the children.

Gisèle Ahou Yah KOUA, Konan Evrad Brice DIBI, Edwige Essoma AKOA, Sébastien NIAMKE, Development of enriched cupcakes and cookies with orange-fleshed sweet potato (Ipomea batatas L.): sensory and nutritional evaluation, Food and Environment Safety, Volume XX, Issue 2 - 2021, pag. 137 - 148 
Table 1:

Proximate composition of cupcake made from wheat flour and OFSP flour and control (100g of dry weight)

\begin{tabular}{|c|c|c|c|c|c|c|}
\hline Samples & $\begin{array}{l}\text { Wheat:OFSP } \\
(\mathrm{w} / \mathrm{w})\end{array}$ & Moisture (\%) & Ash (\%) & Lipid (\%) & Fiber $(\%)$ & Protein $(\%)$ \\
\hline Control & 100:00 & $14.18 \pm 0.04^{\mathrm{g}}$ & $1.52 \pm 0.30^{\mathrm{d}}$ & $18.97 \pm 0.45^{\mathrm{a}}$ & $1.52 \pm 0.22^{\mathrm{h}}$ & $12.11 \pm 0.66^{\mathrm{a}}$ \\
\hline \multirow{4}{*}{ Irene } & $85: 15$ & $14.82 \pm 0.04^{\mathrm{efg}}$ & $1.64 \pm 0.10^{\mathrm{cd}}$ & $18.63 \pm 0.05^{\mathrm{bc}}$ & $5.38 \pm 0.16^{\mathrm{g}}$ & $11.37 \pm 1.03^{\mathrm{a}}$ \\
\hline & $75: 25$ & $15.23 \pm 0.07^{\text {cdef }}$ & $1.71 \pm 0.02^{\mathrm{bcd}}$ & $18.36 \pm 0.30^{c}$ & $5.51 \pm 0.69^{\mathrm{g}}$ & $11.46 \pm 0.83^{\mathrm{ab}}$ \\
\hline & $65: 35$ & $15.75 \pm 0.13^{\mathrm{bcd}}$ & $1.83 \pm 0.02^{\mathrm{abc}}$ & $17.90 \pm 0.02^{\mathrm{d}}$ & $6.10 \pm 0.04^{\mathrm{ef}}$ & $10.96 \pm 0.95^{\mathrm{abc}}$ \\
\hline & $50: 50$ & $16.24 \pm 0.51^{\mathrm{ab}}$ & $1.89 \pm 0.05^{\mathrm{ab}}$ & $17.81 \pm 0.11^{\mathrm{d}}$ & $6.19 \pm 0.06^{\mathrm{e}}$ & $10.57 \pm 0.59^{\mathrm{abc}}$ \\
\hline \multirow{4}{*}{ Kabode } & $85: 15$ & $14.54 \pm 0.04^{\mathrm{fg}}$ & $1.64 \pm 0.10^{\mathrm{cd}}$ & $18.78 \pm 0.13^{\mathrm{ab}}$ & $5.73 \pm 0.21^{\mathrm{fg}}$ & $11.33 \pm 1.21^{\mathrm{ab}}$ \\
\hline & $75: 25$ & $15.04 \pm 0.48^{\mathrm{def}}$ & $1.81 \pm 0.02^{\mathrm{abc}}$ & $18.61 \pm 0.06^{\mathrm{bc}}$ & $5.51 \pm 0.32^{\mathrm{g}}$ & $11.44 \pm 0.36^{\mathrm{ab}}$ \\
\hline & $65: 35$ & $16.00 \pm 0.56^{\mathrm{abc}}$ & $1.96 \pm 0.22^{\mathrm{a}}$ & $18.56 \pm 0.03^{\mathrm{bc}}$ & $6.30 \pm 0.20^{\mathrm{de}}$ & $10.84 \pm 0.61^{\mathrm{abc}}$ \\
\hline & $50: 50$ & $16.17 \pm 0.15^{\mathrm{ab}}$ & $1.98 \pm 0.03^{\mathrm{a}}$ & $18.44 \pm 0.23^{\mathrm{c}}$ & $6.29 \pm 0.12^{\mathrm{de}}$ & $10.71 \pm 0.56^{\mathrm{abc}}$ \\
\hline \multirow{4}{*}{ Covington } & $85: 15$ & $14.76 \pm 0.16^{\mathrm{efg}}$ & $1.84 \pm 0.18^{\mathrm{abc}}$ & $18.66 \pm 0.05^{\mathrm{bc}}$ & $6.68 \pm 0.05^{\mathrm{cd}}$ & $10.96 \pm 1.70^{\mathrm{abc}}$ \\
\hline & $75: 25$ & $15.55 \pm 0.38^{\text {bcde }}$ & $1.86 \pm 0.08^{\mathrm{ab}}$ & $18.59 \pm 0.10^{\mathrm{bc}}$ & $7.11 \pm 0.08^{\mathrm{bc}}$ & $10.56 \pm 0.77^{\mathrm{abc}}$ \\
\hline & $65: 35$ & $16.02 \pm 1.12^{\mathrm{abc}}$ & $1.89 \pm 0.07^{\mathrm{ab}}$ & $18.52 \pm 0.02^{\mathrm{bc}}$ & $7.64 \pm 0.26^{\mathrm{a}}$ & $10.30 \pm 0.40^{\mathrm{bc}}$ \\
\hline & $50: 50$ & $16.79 \pm 0.04^{\mathrm{a}}$ & $1.94 \pm 0.04^{\mathrm{a}}$ & $18.37 \pm 0.20^{\mathrm{c}}$ & $7.32 \pm 0.18^{\mathrm{ab}}$ & $9.60 \pm 0.28^{c}$ \\
\hline
\end{tabular}

(Table continued)

\begin{tabular}{ccccc}
\hline Samples & $\begin{array}{c}\text { Wheat:OFSP } \\
(\mathrm{w} / \mathrm{w})\end{array}$ & Carbohydrate $(\%)$ & Energy value (kcal) & $\begin{array}{c}\text { Total provitamin A } \\
(\mu \mathrm{g})\end{array}$ \\
\hline Control & $100: 00$ & $51.70 \pm 1.46^{\mathrm{a}}$ & $425.99 \pm 0.87^{\mathrm{a}}$ & - \\
\hline \multirow{2}{*}{ Irene } & $85: 15$ & $48.17 \pm 1.06^{\mathrm{b}}$ & $405.77 \pm 0.92^{\mathrm{b}}$ & $1138.68 \pm 14.051^{\mathrm{j}}$ \\
& $75: 25$ & $47.72 \pm 1.72^{\mathrm{bc}}$ & $401.99 \pm 1.24^{\mathrm{cd}}$ & $1421.21 \pm 8.45^{\mathrm{gh}}$ \\
& $65: 35$ & $47.45 \pm 1.08^{\mathrm{bc}}$ & $394.80 \pm 0.43^{\mathrm{ef}}$ & $1873.12 \pm 10.11^{\mathrm{e}}$ \\
& $50: 50$ & $47.29 \pm 0.97^{\mathrm{bc}}$ & $391.76 \pm 2.01^{\mathrm{fg}}$ & $2589.91 \pm 9.52^{\mathrm{b}}$ \\
\hline \multirow{3}{*}{ Kabode } & $85: 15$ & $47.97 \pm 1.21^{\mathrm{b}}$ & $406.28 \pm 1.26^{\mathrm{b}}$ & $1031.04 \pm 6.36^{\mathrm{k}}$ \\
& $75: 25$ & $47.59 \pm 0.57^{\mathrm{bc}}$ & $403.59 \pm 1.09^{\mathrm{bc}}$ & $1269.38 \pm 10.12^{\mathrm{i}}$ \\
& $65: 35$ & $46.34 \pm 1.29^{\mathrm{bc}}$ & $395.79 \pm 1.37^{\mathrm{e}}$ & $1486.68 \pm 8.76^{\mathrm{g}}$ \\
& $50: 50$ & $46.42 \pm 0.53^{\mathrm{bc}}$ & $394.45 \pm 10.34^{\mathrm{ef}}$ & $1769.78 \pm 14.44^{\mathrm{f}}$ \\
\hline \multirow{2}{*}{ Covington } & $85: 15$ & $47.10 \pm 1.61^{\mathrm{bc}}$ & $400.16 \pm 0.88^{\mathrm{d}}$ & $1332.39 \pm 8.58^{\mathrm{hi}}$ \\
& $75: 25$ & $46.33 \pm 1.19^{\mathrm{bc}}$ & $394.91 \pm 1.74^{\mathrm{ef}}$ & $2155.29 \pm 10.56^{\mathrm{d}}$ \\
& $65: 35$ & $45.64 \pm 0.68^{\mathrm{c}}$ & $390.40 \pm 1.53^{\mathrm{gh}}$ & $2443.88 \pm 6.83^{\mathrm{c}}$ \\
\hline
\end{tabular}

Values are averages of triplicate replicates. Data is represented as mean \pm standard deviation. Means in the same column with different superscript letters ( $a, b, c, d$, e, etc...) are significantly different $(P<0.05)$.

Samples ratios are represented as Wheat: OFSPexpressed in proportion $(w / w)$ expressed in weight $(g)$ per weight $(g)$.

Gisèle Ahou Yah KOUA, Konan Evrad Brice DIBI, Edwige Essoma AKOA, Sébastien NIAMKE, Development of enriched cupcakes and cookies with orange-fleshed sweet potato (Ipomea batatas L.): sensory and nutritional evaluation, Food and Environment Safety, Volume XX, Issue 2 - 2021, pag. 137 - 148 
Table 2:

Proximate composition of cookies made from wheat flour and OFSP flour (100g of dry weight)

\begin{tabular}{ccccccc}
\hline \multirow{2}{*}{ Samples } & $\begin{array}{c}\text { Wheat: OFSP } \\
(\mathrm{w} / \mathrm{w})\end{array}$ & Moisture $(\%)$ & Ash $(\%)$ & Lipid $(\%)$ & Fiber (\%) & Protein $(\%)$ \\
\hline Control & $100: 0$ & $4.14 \pm 0.40^{\mathrm{k}}$ & $1.01 \pm 0.10^{\mathrm{f}}$ & $22.59 \pm 0.27^{\mathrm{a}}$ & $2.51 \pm 0.12^{\mathrm{f}}$ & $12.95 \pm 0.03^{\mathrm{a}}$ \\
\hline \multirow{3}{*}{ Irene } & $85: 15$ & $4.58 \pm 0.06^{\mathrm{j}}$ & $1.02 \pm 0.06^{\mathrm{f}}$ & $21.83 \pm 0.27^{\mathrm{b}}$ & $6.22 \pm 0.21^{\mathrm{cd}}$ & $12.27 \pm 0.12^{\mathrm{abc}}$ \\
& $75: 25$ & $5.24 \pm 0.17^{\mathrm{h}}$ & $1.18 \pm 0.06^{\mathrm{d}}$ & $21.80 \pm 0.33^{\mathrm{b}}$ & $6.73 \pm 0.22^{\mathrm{bc}}$ & $12.21 \pm 0.12^{\mathrm{abc}}$ \\
& $65: 35$ & $6.33 \pm 0.04^{\mathrm{c}}$ & $1.28 \pm 0.11^{\mathrm{c}}$ & $21.67 \pm 0.31^{\mathrm{b}}$ & $7.29 \pm 0.26^{\mathrm{a}}$ & $11.49 \pm 0.80^{\mathrm{bc}}$ \\
& $50: 50$ & $6.32 \pm 0.04^{\mathrm{c}}$ & $1.31 \pm 0.31^{\mathrm{c}}$ & $20.67 \pm 0.44^{\mathrm{de}}$ & $7.70 \pm 0.20^{\mathrm{a}}$ & $11.13 \pm 1.06^{\mathrm{c}}$ \\
\hline \multirow{3}{*}{ Kabode } & $85: 15$ & $5.47 \pm 0.15^{\mathrm{fg}}$ & $1.16 \pm 0.12^{\mathrm{d}}$ & $21.67 \pm 0.41^{\mathrm{b}}$ & $5.39 \pm 0.13^{\mathrm{e}}$ & $12.62 \pm 0.04^{\mathrm{ab}}$ \\
& $75: 25$ & $5.69 \pm 0.10^{\mathrm{e}}$ & $1.17 \pm 0.04^{\mathrm{d}}$ & $21.27 \pm 0.73^{\mathrm{bcd}}$ & $6.15 \pm 0.11^{\mathrm{d}}$ & $12.43 \pm 0.10^{\mathrm{abc}}$ \\
& $65: 35$ & $6.16 \pm 0.10^{\mathrm{d}}$ & $1.44 \pm 0.15^{\mathrm{b}}$ & $21.18 \pm 0.09^{\mathrm{bcde}}$ & $6.53 \pm 0.30^{\mathrm{cd}}$ & $11.82 \pm 0.59^{\mathrm{abc}}$ \\
& $50: 50$ & $7.91 \pm 0.08^{\mathrm{a}}$ & $1.71 \pm 0.05^{\mathrm{a}}$ & $20.48 \pm 0.39^{\mathrm{e}}$ & $7.68 \pm 0.47^{\mathrm{a}}$ & $11.50 \pm 0.06^{\mathrm{bc}}$ \\
\hline \multirow{5}{*}{ Covington } & $85: 15$ & $4.79 \pm 0.12^{\mathrm{i}}$ & $1.11 \pm 0.03^{\mathrm{e}}$ & $21.48 \pm 0.36^{\mathrm{bc}}$ & $6.03 \pm 0.14^{\mathrm{d}}$ & $12.52 \pm 0.13^{\mathrm{ab}}$ \\
& $75: 25$ & $5.33 \pm 0.03^{\mathrm{gh}}$ & $1.17 \pm 0.08^{\mathrm{d}}$ & $21.05 \pm 0.33^{\mathrm{bcd}}$ & $6.58 \pm 0.42^{\mathrm{cd}}$ & $12.36 \pm 0.26^{\mathrm{abc}}$ \\
& $65: 35$ & $5.60 \pm 0.10^{\mathrm{ef}}$ & $1.19 \pm 0.07^{\mathrm{d}}$ & $21.05 \pm 0.36^{\mathrm{bcde}}$ & $7.16 \pm 0.10^{\mathrm{ab}}$ & $12.18 \pm 0.27^{\mathrm{abc}}$ \\
& $50: 50$ & $7.24 \pm 0.20^{\mathrm{b}}$ & $1.42 \pm 0.11^{\mathrm{b}}$ & $20.74 \pm 0.31^{\mathrm{cde}}$ & $7.26 \pm 0.22^{\mathrm{ab}}$ & $11.90 \pm 0.65^{\mathrm{abc}}$ \\
\hline
\end{tabular}

(Table continued)

\begin{tabular}{ccccc}
\hline Samples & $\begin{array}{c}\text { Wheat: OFSP } \\
(\mathrm{w} / \mathrm{w})\end{array}$ & Carbohydrate $(\%)$ & $\begin{array}{c}\text { Energy value } \\
(\mathrm{kcal})\end{array}$ & $\begin{array}{c}\text { Total Provitamin A } \\
(\mu \mathrm{g})\end{array}$ \\
\hline Control & $100: 0$ & $56.80 \pm 0.28^{\mathrm{a}}$ & $482.35 \pm 0.28^{\mathrm{a}}$ & - \\
\hline \multirow{3}{*}{ Irene } & $85: 15$ & $54.08 \pm 1.00^{\mathrm{b}}$ & $461.86 \pm 1.00^{\mathrm{b}}$ & $1055.67 \pm 11.14^{\mathrm{h}}$ \\
& $75: 25$ & $52.83 \pm 1.01^{\mathrm{bcd}}$ & $456.37 \pm 0.90^{\mathrm{c}}$ & $1512.91 \pm 10.05^{\mathrm{g}}$ \\
& $65: 35$ & $51.95 \pm 0.80^{\text {cde }}$ & $448.79 \pm 0.88^{\mathrm{d}}$ & $1984.23 \pm 10.56^{\mathrm{f}}$ \\
& $50: 50$ & $52.87 \pm 0.19^{\mathrm{bcd}}$ & $442.02 \pm 0.40^{\mathrm{e}}$ & $2555.27 \pm 18.28^{\mathrm{d}}$ \\
\hline \multirow{2}{*}{ Kabode } & $85: 15$ & $53.68 \pm 0.72^{\mathrm{b}}$ & $460.28 \pm 1.49^{\mathrm{b}}$ & $1009.57 \pm 8.38^{\mathrm{h}}$ \\
& $75: 25$ & $53.28 \pm 0.47^{\mathrm{bc}}$ & $454.30 \pm 1.63^{\mathrm{c}}$ & $1430.14 \pm 10.40^{\mathrm{g}}$ \\
& $65: 35$ & $52.87 \pm 0.50^{\mathrm{bcd}}$ & $449.41 \pm 0.76^{\mathrm{d}}$ & $1648.68 \pm 11.77^{\mathrm{g}}$ \\
& $50: 50$ & $50.71 \pm 0.58^{\mathrm{e}}$ & $433.20 \pm 1.41^{\mathrm{f}}$ & $2290.89 \pm 7.56^{\mathrm{e}}$ \\
\hline \multirow{2}{*}{ Covington } & $85: 15$ & $54.08 \pm 0.25^{\mathrm{b}}$ & $459.73 \pm 0.37^{\mathrm{b}}$ & $2155.55 \pm 12.63^{\mathrm{ef}}$ \\
& $75: 25$ & $53.18 \pm 0.40^{\mathrm{bc}}$ & $454.57 \pm 1.24^{\mathrm{c}}$ & $2814.36 \pm 8.93^{\mathrm{c}}$ \\
& $65: 35$ & $52.81 \pm 0.22^{\mathrm{bcd}}$ & $449.42 \pm .1 .54^{\mathrm{d}}$ & $3588.98 \pm 10.55^{\mathrm{b}}$ \\
& $50: 50$ & $51.43 \pm 0.32^{\mathrm{de}}$ & $440.00 \pm 1.20^{\mathrm{e}}$ & $4640.72 \pm 12.43^{\mathrm{a}}$ \\
\hline
\end{tabular}

Values are averages of triplicate replicates. Data is represented as mean \pm standard deviation. Means in the same column with different superscript letters $(a, b, c, d$, e, etc...) are significantly different $(P<0.05)$.

Samples ratios are represented as wheat:OFSPexpressed in proportion weight $(g)$ per weight $(g)(w / w)$.

As expected, the cupcake and cookies made of $100 \%$ wheat flour (control) had the highest protein content. This result could be attributed to the lower concentration of protein in OFSP flour compared to wheat flour. Furthermore, substitution of wheat flour withOFSPflour showed a reduction of carbohydrate and

Gisèle Ahou Yah KOUA, Konan Evrad Brice DIBI, Edwige Essoma AKOA, Sébastien NIAMKE, Development of enriched cupcakes and cookies with orange-fleshed sweet potato (Ipomea batatas L.): sensory and nutritional evaluation, Food and Environment Safety, Volume XX, Issue 2 - 2021, pag. 137 - 148 
energy contents of cupcakes and cookies. The carbohydrate content of cupcakes and cookies were significantly $(p<0.05)$ lower than that of control. As concern energy parameter, the highest value was observed for controls $(425.99 \pm 0.87 \mathrm{kcal} / 100 \mathrm{~g} \mathrm{dw}$ and $482.35 \pm 0.28 \mathrm{kcal} / 100 \mathrm{~g} \quad \mathrm{dw}$, respectively for cupcakes and cookies). The lowest of energy was for $50 \%$ supplemented OFSP cupcakes (387.68 $\pm 0.77 \mathrm{kcal} / 100 \mathrm{~g} \mathrm{dw})$ and cookies $(433.20 \pm 1.41 \mathrm{kcal} / 100 \mathrm{~g} \mathrm{dw})$. This may be due to the lower contents of fat, proteins, and carbohydrates of different formulations when OFSP flour increases. The incorporation of OFSP flour in the processing of cupcakes and cookies contributed significantly to enhance vitamin A content of baked products. The provitamin A content increased from $1031.04 \pm 6.36$ to $3364.21 \pm 14.73 \mu \mathrm{g} / 100 \mathrm{~g}$ $\mathrm{dw}$ of $50 \%$ OFSP cupcakes (Table 1). As concern formulated cookies, provitamin A contents varied from $1009.57 \pm 8.38$ to
$4641.72 \pm 12.43 \mu \mathrm{g} / 100 \mathrm{~g} \quad \mathrm{dw}$ (Table 2). These findings were consistent with results of [42], [43], which indicated that increase of provitamin A content in composite products (bread, cake, cookies, etc.) is essentially due to higher value of $\beta$ carotene of OFSP flour. Based on the $\beta$ carotene conversion into vitamin A [22], consumption of one piece of enriched OFSP cupcakes (approximately 60g/piece) and two pieces of cookies (approximately $44 \mathrm{~g} /$ piece) could meet $21.43 \%$ to $70.08 \%$ and $21.02 \%$ to $96.69 \%$ of vitamin A requirements of preschool children (1-3 years old) (Figure $1 \mathrm{~A}$ and $\mathrm{B}$ ). This suggests that consumption of enriched OFSP cupcakes and cookies could reduce Vitamin ADeficiency (VAD) in children and other consumers (pregnant/lactating women), especially the populations of the North and Nort-East, where the prevalence of vitamin A deficiency is estimated at $24 \%[4]$
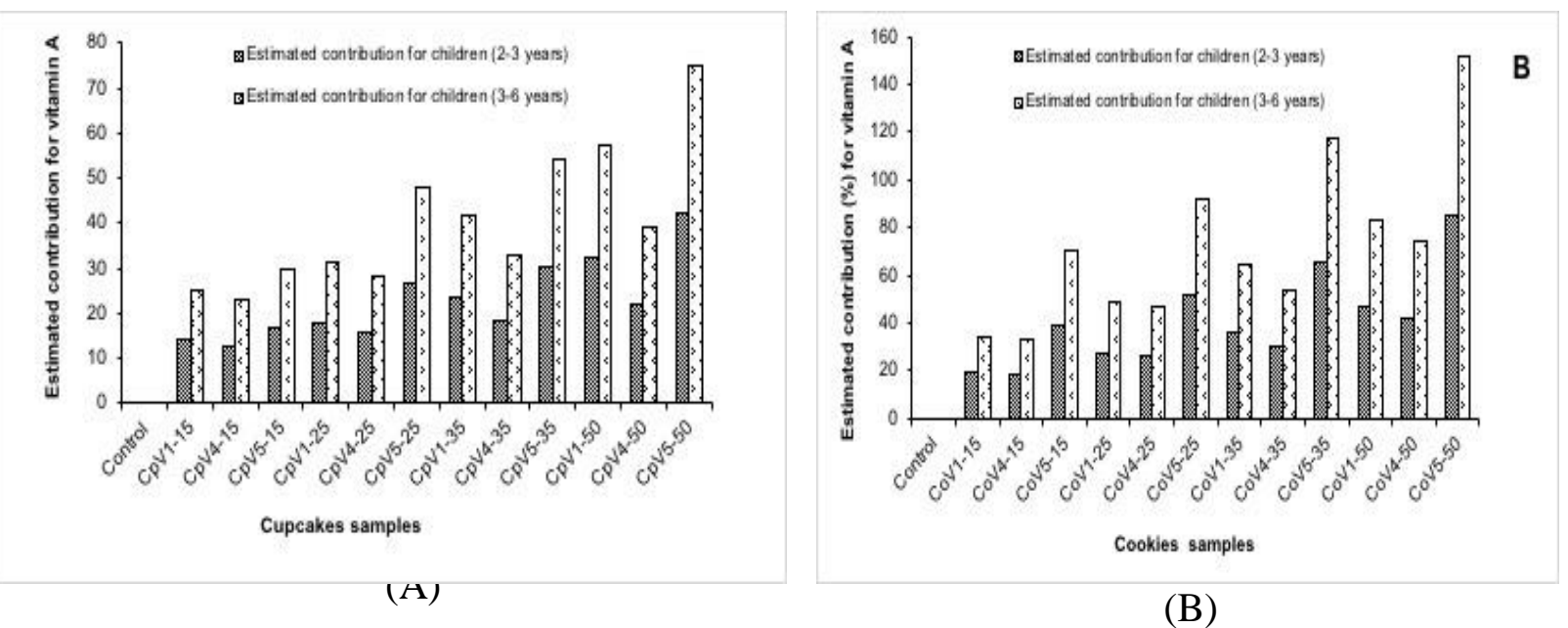

Fig. 1: Estimated contribution (\%) of OFSP composite flour snack foods to RDA for vitamin A for children between 2 and 6 years old.

RDA: Recommended Dietary Allowance; contribution was determined based on an assumed serving one piece of cupcake (approximatively 60g) or two pieces of cookie (approximatively 44g) for 2 and 3 years old, and two pieces of cupcake (approximatively 120g) or four pieces of cookie (approximatively 176g) for 3 and 6years old. Cp: cupcake; Co: cookie; V1, V4, V5: represent different OFSP cultivars V1: Irene, V4: Kabode, V5: Covington

15; 25; 35; 50: represent different proportions of OFSP incorporated to wheat flour.

Gisèle Ahou Yah KOUA, Konan Evrad Brice DIBI, Edwige Essoma AKOA, Sébastien NIAMKE, Development of enriched cupcakes and cookies with orange-fleshed sweet potato (Ipomea batatas L.): sensory and nutritional evaluation, Food and Environment Safety, Volume XX, Issue 2 - 2021, pag. 137 - 148 


\subsection{Microbiologyqualityof the composite OFSP flour baked products}

The result of this study indicated that there was a significant difference $(\mathrm{p}<0.05)$ among the counts of Aerobic colony count (ACC) of all the baked products. These values ranged from $3.32 \pm 0.38$ to $4.17 \pm 0.35$ $\log$ CFU/g for cupcakes (Table 3). For cookies, the value varied between $3.00 \pm 0.17$ and $4.47 \pm 0.09 \log \mathrm{CFU} / \mathrm{g}$, with the highest value recorded for control and lowest value for cookie prepared with OFSP cultivar Covington (Table 4). Spoilage bacteria (Enterobacteria, ASB,Staphylococcus aureus, Salmonella, ...) were not detected in all the baked products formulated. The lower value of microorganisms count may be explained by the baking step which occurs at $180^{\circ} \mathrm{C}$ for $5 \mathrm{~min}$. In addition, the absence of the hygiene indicators microorganisms (Enterobacteriaceae) in the samples indicated a good cooking practice.

Table 3

Microbial load on composite OFSP flour cupcakes (log10 CFU/g)

\begin{tabular}{lcccccc}
\hline Cupcakes & ACC & Enterobacteria & Yeast/Mould & ASB & Staph. aureus & Salmonella sp. \\
\hline Irene & $3.52 \pm 0.08^{\mathrm{b}}$ & 0 & 0 & 0 & 0 & Absence \\
Kabode & $4.00 \pm 0.19^{\mathrm{a}}$ & 0 & 0 & 0 & 0 & Absence \\
Covington & $4.17 \pm 0.35^{\mathrm{a}}$ & 0 & 0 & 0 & 0 & Absence \\
Control & $3.32 \pm 0.38^{\mathrm{b}}$ & 0 & 0 & 0 & 0 & Absence \\
\hline
\end{tabular}

Table 4

Microbial load on composite OFSP flour cookies $(\log 10 \mathrm{CFU} / \mathrm{g})$

\begin{tabular}{lcccccc}
\hline Cookies & ACC & Enterobacteria & Yeast/Mould & ASB & Staph. aureus & Salmonella sp \\
\hline Irene & $3.00 \pm 0.17^{\mathrm{co}}$ & 0 & 0 & 0 & 0 & Absence \\
Kabode & $4.20 \pm 0.22^{\mathrm{a}}$ & 0 & 0 & 0 & 0 & Absence \\
Covington & $3.30 \pm 0.05^{\mathrm{co}}$ & 0 & 0 & 0 & 0 & Absence \\
Control & $4.47 \pm 0.09^{\mathrm{a}}$ & 0 & 0 & 0 & 0 & Absence \\
\hline
\end{tabular}

Values are averages of triplicate replicates. Data is represented as mean \pm standard deviation. Means in the same column with different superscript letters $(a, b, c, \ldots)$ are significantly different $(p<0.05)$.

ACC: Aerobic Colony Count; ASB: Anaerobic Sulphur-reducing Bacteria; Staph. aureus:

Staphylococcusaureus.

\subsection{Sensory evaluation of the of the composite OFSP flour baked products}

Promote quality control and marketing of new products or recipes formulated, sensory evaluation constitute an important criteria to consider[44]. In this study, sensory attributes such as appearance, color, taste, aroma, texture, mouth-feel, and overall acceptability were considered.
The result of sensory evaluation showed that cupcakes had less scores than that of the control for all the attributes except for colorand taste (Table 5). These results were similar to those obtained by [35] who reported that cakes prepared with orangefleshed sweet potato, received a lower score than the control for sensory attributes. Results also showed that the cupcakes were accepted by panelists

Gisèle Ahou Yah KOUA, Konan Evrad Brice DIBI, Edwige Essoma AKOA, Sébastien NIAMKE, Development of enriched cupcakes and cookies with orange-fleshed sweet potato (Ipomea batatas L.): sensory and nutritional evaluation, Food and Environment Safety, Volume XX, Issue 2 - 2021, pag. 137 - 148 
regarding color. This showed that panelists prefer orange color of cupcakes rather than the yellow color of the control. Concerning appearance acceptability, a high score was obtained for the control cupcake followed by cupcakes supplemented with 15, 25, 35, and $50 \%$ OFSP. Results also revealed that appearance acceptability increased with the addition of OFSP flour as previously reported by [36].

The taste acceptability scores of cupcakes ranged between $7.50 \pm 0.46$ and $8.51 \pm 0.78$. Cupcakes supplemented with $50 \%$ OFSP flour recorded high score for all the three cultivars. This result may be attributed to natural sweet taste of OFSP flour that contributes to increase preference of panelists, as mentioned by [41]. However, the scores of texture and mouthfeel which reflect softness and chewiness of cupcakes decreased with addition of OFSP flour as shown in Table 4. According to previous reports [45], substitution of wheat flour by OFSP flour contributes to add more compact texture. The overall acceptability score of cupcakes varied significantly. The maximum score value $(8.25 \pm 0.37)$ was obtained by control cupcake; while minimum score value $(5,74 \pm 0.07)$ was noted for cupcake containing 50\% OFSP. As concern cookies, the sensory properties are indicated in Table 6. The cookies supplemented with 15 to $35 \%$ of OFSP flour had the highest sensory rating. From all the sensory scores above, it was quite apparent that cupcakes and cookies containing up to $40 \%$ OFSP flours.

Table 5

Sensory evaluation of cupcakes developed from composite flours.

\begin{tabular}{|c|c|c|c|c|c|c|c|c|}
\hline Samples & $\begin{array}{l}\text { Wheat: } \\
\text { OFSP } \\
\text { (w/w) }\end{array}$ & Appearance & Color & Taste & Aroma & Texture & Mouthfeel & $\begin{array}{c}\text { Overall } \\
\text { acceptability }\end{array}$ \\
\hline Control & 100:0 & $8,26 \pm 1.13^{\mathrm{a}}$ & $6.06 \pm 0.17^{f}$ & $7.50 \pm 0.46^{\mathrm{e}}$ & $7.59 \pm 0.63$ & $3.36 \pm 1.31$ & $8.01 \pm 0.42^{\mathrm{a}}$ & $8.25 \pm 0.37^{\mathrm{a}}$ \\
\hline \multirow{4}{*}{ Irene } & $85: 15$ & $7,79 \pm 0.60^{\mathrm{bc}}$ & $6.17 \pm 0.93^{\mathrm{d}}$ & $7.88 \pm 1.02^{\text {bcde }}$ & $7.39 \pm 0.77^{\mathrm{ab}}$ & $6.98 \pm 0.77^{b c}$ & $7.53 \pm 1.22^{\mathrm{b}}$ & $7.61 \pm 0.99^{b}$ \\
\hline & $75: 25$ & $7,04 \pm 1.14^{\mathrm{cd}}$ & $6.39 \pm 0.78^{\mathrm{cd}}$ & $7.95 \pm 1.05^{\text {bcde }}$ & $7.07 \pm 0.80^{\mathrm{bcd}}$ & $6.66 \pm 0.50^{\mathrm{cd}}$ & $7.13 \pm 2.18^{\mathrm{bcd}}$ & $7.22 \pm 1.30^{\mathrm{bcd}}$ \\
\hline & $65: 35$ & $6,22 \pm 1.15^{\mathrm{f}}$ & $7,67 \pm 0.65^{\mathrm{bc}}$ & $8.06 \pm 0.77^{\mathrm{abcd}}$ & $6.93 \pm 1.10^{\mathrm{cd}}$ & $6.30 \pm 0.40^{\mathrm{de}}$ & $6.72 \pm 1.20^{\mathrm{de}}$ & $6.98 \pm 0.86^{\mathrm{cd}}$ \\
\hline & $50: 50$ & $5,41 \pm 2.36^{\mathrm{g}}$ & $7.79 \pm 0.88^{\mathrm{ab}}$ & $8.25 \pm 0.89^{\mathrm{ab}}$ & $5.89 \pm 0.41^{\mathrm{e}}$ & $5.48 \pm 0.21^{\mathrm{f}}$ & $5.06 \pm 2.04^{\mathrm{f}}$ & $5.96 \pm 0.85^{\mathrm{e}}$ \\
\hline \multirow{4}{*}{ Kabode } & $85: 15$ & $7,26 \pm 2.05^{\mathrm{cd}}$ & $7.07 \pm 0.61^{\mathrm{e}}$ & $7.54 \pm 1.17^{\mathrm{de}}$ & $7.25 \pm 1.12^{\mathrm{bc}}$ & $7.19 \pm 0.82^{\mathrm{b}}$ & $7.40 \pm 0.66^{\mathrm{bc}}$ & $7.38 \pm 0.63^{\mathrm{bc}}$ \\
\hline & $75: 25$ & $6,85 \pm 1.09^{\text {cde }}$ & $7.46 \pm 0.61^{\mathrm{cd}}$ & $7.70 \pm 1.20^{\text {cde }}$ & $7.09 \pm 0.37^{\mathrm{bcd}}$ & $6.55 \pm 0.57^{\text {cde }}$ & $7.12 \pm 0.53^{\mathrm{bcd}}$ & $7.15 \pm 1.12^{\mathrm{cd}}$ \\
\hline & $65: 35$ & $6,41 \pm 1.27^{\mathrm{ef}}$ & $7.73 \pm 0.75^{\mathrm{ab}}$ & $7.93 \pm 0.86^{\text {bcde }}$ & $6.88 \pm 1.08^{\mathrm{cd}}$ & $6.15 \pm 0.88^{\mathrm{e}}$ & $6.66 \pm 1.10^{\mathrm{ef}}$ & $6.83 \pm 0.74^{\mathrm{d}}$ \\
\hline & $50: 50$ & $5,20 \pm 2.28^{\mathrm{g}}$ & $7.81 \pm 1.12^{\mathrm{a}}$ & $8.08 \pm 1.03^{\mathrm{abc}}$ & $5.39 \pm 0.80^{\mathrm{f}}$ & $5.04 \pm 0.28^{\mathrm{g}}$ & $5.03 \pm 0.82^{\mathrm{f}}$ & $5.70 \pm 1.04^{e}$ \\
\hline \multirow{4}{*}{ Covington } & $85: 15$ & $7,94 \pm 2.06^{\mathrm{cd}}$ & $7.40 \pm 0.63^{\mathrm{c}}$ & $7.55 \pm 1.09^{\mathrm{de}}$ & $7.45 \pm 1.05^{\mathrm{ab}}$ & $7.21 \pm 1.05^{\mathrm{b}}$ & $7.37 \pm 1.03^{\mathrm{bc}}$ & $7.61 \pm 0.80^{b}$ \\
\hline & $75: 25$ & $7,33 \pm 1.19^{\mathrm{cd}}$ & $7.48 \pm 0.55^{\mathrm{ab}}$ & $7.92 \pm 0.47^{\text {bcde }}$ & $6.88 \pm 0.69^{\mathrm{cd}}$ & $6.97 \pm 0.90^{\mathrm{bc}}$ & $7.19 \pm 0.93^{\mathrm{bc}}$ & $7.40 \pm 1.07^{\mathrm{bc}}$ \\
\hline & $65: 35$ & $6,88 \pm 2.14^{\mathrm{de}}$ & $7.75 \pm 0.88^{\mathrm{a}}$ & $8.06 \pm 0.93^{\mathrm{abc}}$ & $6.67 \pm 0.50^{\mathrm{d}}$ & $6.94 \pm 1.10^{\mathrm{bc}}$ & $6.97 \pm 2.09^{\text {cde }}$ & $7.30 \pm 0.57^{\mathrm{bc}}$ \\
\hline & $50: 50$ & $5,16 \pm 1.22^{\mathrm{g}}$ & $7.92 \pm 0.12^{\mathrm{a}}$ & $8.51 \pm 0.78^{a}$ & $5.37 \pm 0.83^{f}$ & $5.16 \pm 0.43^{\mathrm{g}}$ & $5.43 \pm 0.71^{\mathrm{f}}$ & $5.74 \pm 0.07^{\mathrm{e}}$ \\
\hline
\end{tabular}

Values are averages of triplicate replicates. Data is represented as mean \pm standard deviation. Means in the same column with different superscript letters $(a, b, c, d$, e, etc...) are significantly different $(P<0.05)$.

Samples ratios are represented as Wheat: OFSP expressed in proportion $(w / w)$ expressed in weight $(g)$ per weight $(g)$.

Gisèle Ahou Yah KOUA, Konan Evrad Brice DIBI, Edwige Essoma AKOA, Sébastien NIAMKE, Development of enriched cupcakes and cookies with orange-fleshed sweet potato (Ipomea batatas L.): sensory and nutritional evaluation, Food and Environment Safety, Volume XX, Issue 2 - 2021, pag. 137 - 148 
Sensory evaluation of cookies developed from composite flours.

\begin{tabular}{|c|c|c|c|c|c|c|c|c|}
\hline Samples & $\begin{array}{l}\text { Wheat: } \\
\text { OFSP } \\
\text { (w/w) }\end{array}$ & Appearance & Color & Taste & Aroma & Texture & Mouthfeel & $\begin{array}{l}\text { Overall } \\
\text { acceptability }\end{array}$ \\
\hline Control & 100:0 & $8.00 \pm 0.38^{\mathrm{a}}$ & $6.37 \pm 0.70^{\mathrm{d}}$ & $7.00 \pm 1.10^{\mathrm{e}}$ & $8.02 \pm 0.33^{\mathrm{a}}$ & $8.10 \pm 1.10^{\mathrm{a}}$ & $8.48 \pm 0.33^{\mathrm{a}}$ & $8.15 \pm 0.27^{\mathrm{a}}$ \\
\hline \multirow{4}{*}{ Irene } & $85: 15$ & $7.88 \pm 0.33^{\mathrm{ab}}$ & $6.47 \pm 1.07^{\mathrm{cd}}$ & $7.22 \pm 0.55^{\mathrm{de}}$ & $7.59 \pm 0.47^{\mathrm{ab}}$ & $7.91 \pm 0.25^{\mathrm{ab}}$ & $7.74 \pm 0.27^{\mathrm{ab}}$ & $7.77 \pm 0.30^{\mathrm{a}}$ \\
\hline & $75: 25$ & $7.36 \pm 0.61^{\mathrm{bcd}}$ & $7.05 \pm 0.41^{\mathrm{abcd}}$ & $7.50 \pm 1.14^{\mathrm{cd}}$ & $6.81 \pm 0.44^{\mathrm{cd}}$ & $7.49 \pm 0.14^{\mathrm{abc}}$ & $7.13 \pm 0.14^{b c}$ & $7.53 \pm 0.37^{\mathrm{ab}}$ \\
\hline & $65: 35$ & $7.08 \pm 0.77^{\text {cde }}$ & $7.44 \pm 0.77^{\mathrm{ab}}$ & $7.97 \pm 0.13^{\mathrm{ab}}$ & $6.57 \pm 1.05^{\mathrm{de}}$ & $7.07 \pm 0.14^{\mathrm{cd}}$ & $6.60 \pm 0.25^{\mathrm{cd}}$ & $7.02 \pm 0.42^{\mathrm{bc}}$ \\
\hline & $50: 50$ & $6.72 \pm 1.07^{\mathrm{e}}$ & $7.80 \pm 0.13^{\mathrm{a}}$ & $8.08 \pm 1.13^{\mathrm{a}}$ & $5.47 \pm 0.09^{f}$ & $6.10 \pm 0.13^{\text {ef }}$ & $5.80 \pm 0.69^{\mathrm{d}}$ & $5.72 \pm 0.37^{\mathrm{e}}$ \\
\hline \multirow{4}{*}{ Kabode } & $85: 15$ & $7.60 \pm 1.06^{\mathrm{abc}}$ & $6.38 \pm 0.97^{d}$ & $7.64 \pm 0.63^{\mathrm{bc}}$ & $7.34 \pm 0.47^{\mathrm{bc}}$ & $7.08 \pm 0.53^{\text {cd }}$ & $7.89 \pm 0.57^{\mathrm{ab}}$ & $7.98 \pm 0.49^{\mathrm{a}}$ \\
\hline & $75: 25$ & $6.92 \pm 0.57^{\mathrm{de}}$ & $6.94 \pm 0.32^{\mathrm{bcd}}$ & $7.90 \pm 0.57^{\mathrm{ab}}$ & $7.12 \pm 0.80^{\mathrm{bcd}}$ & $6.57 \pm 0.77^{\mathrm{de}}$ & $7.52 \pm 1.10^{\mathrm{b}}$ & $7.80 \pm 0.30^{\mathrm{a}}$ \\
\hline & $65: 35$ & $6.57 \pm 0.53^{\mathrm{e}}$ & $7.04 \pm 0.54^{\mathrm{abcd}}$ & $7.98 \pm 0.79^{\mathrm{ab}}$ & $6.49 \pm 0.33^{\mathrm{de}}$ & $6.00 \pm 0.39^{\mathrm{ef}}$ & $6.45 \pm 0.13^{\mathrm{cd}}$ & $6.45 \pm 0.29^{\mathrm{cd}}$ \\
\hline & $50: 50$ & $6.01 \pm 0.74^{\mathrm{f}}$ & $7.27 \pm 0.75^{\mathrm{abc}}$ & $8.19 \pm 0.47^{\mathrm{a}}$ & $6.07 \pm 0.76^{\mathrm{ef}}$ & $5.89 \pm 0.97^{\mathrm{ef}}$ & $6.15 \pm 0.37^{\mathrm{d}}$ & $5.68 \pm 0.35^{\mathrm{e}}$ \\
\hline \multirow{4}{*}{ Covington } & $85: 15$ & $7.87 \pm 0.56^{\mathrm{ab}}$ & $6.77 \pm 0.54^{\text {bcd }}$ & $7.11 \pm 0.28^{\mathrm{e}}$ & $7.13 \pm 0.21^{\mathrm{bcd}}$ & $7.67 \pm 0.28^{\mathrm{abc}}$ & $7.89 \pm 0.21^{\mathrm{ab}}$ & $8.06 \pm 0.30^{\mathrm{a}}$ \\
\hline & $75: 25$ & $7.69 \pm 0.31^{\mathrm{ab}}$ & $6.99 \pm 1.07^{\mathrm{abcd}}$ & $7.67 \pm 0.23^{\mathrm{bc}}$ & $6.83 \pm 0.24^{\mathrm{cd}}$ & $7.17 \pm 0.23^{\mathrm{bcd}}$ & $7.56 \pm 0.24^{\mathrm{b}}$ & $7.83 \pm 0.25^{\mathrm{cd}}$ \\
\hline & $65: 35$ & $6.90 \pm 0.24^{\mathrm{de}}$ & $7.33 \pm 0.15^{\mathrm{ab}}$ & $8.11 \pm 0.08^{\mathrm{a}}$ & $6.77 \pm 0.31^{\mathrm{cd}}$ & $6.31 \pm 0.68^{\mathrm{e}}$ & $6.33 \pm 0.31^{\mathrm{cd}}$ & $7.06 \pm 0.40^{\mathrm{bc}}$ \\
\hline & $50: 50$ & $6.56 \pm 0.23^{\mathrm{e}}$ & $7.78 \pm 0.24^{\mathrm{a}}$ & $8.26 \pm 0.24^{\mathrm{a}}$ & $6.00 \pm 0.37^{\mathrm{ef}}$ & $5.35 \pm 0.24^{f}$ & $6.00 \pm 0.07^{\mathrm{d}}$ & $5.84 \pm 0.50^{\mathrm{de}}$ \\
\hline
\end{tabular}

Values are averages of triplicate replicates. Data is represented as mean \pm standard deviation. Means in the same column with different superscript letters ( $a, b, c, d$, e, etc...) are significantly different $(p<0.05)$.

Samples ratios are represented as wheat: OFSP expressed in proportion weight $(g)$ per weight $(g)(w / w)$.

\section{Conclusion}

The findings of this study show that the nutritional composition of the cupcakes and cookies were improved due to OFSP incorporating, while the sensory attributes were overall acceptable. Substitution of wheat flour with OFSP flours resulted in significant increase in pro-vitamin A carotenoid, ash, and fiber contents compared to the control. The sensory evaluation showed that OFSP cupcakes and cookies supplemented up to $35 \%$ OFSP were accepted by the panelists. Moreover, the formulated cupcakes and cookies were of good microbiological quality. Thus, OFSP flour could be recommended to develop complementary foods with improved nutritional properties. This would help fight against child malnutrition in Côte d'Ivoire.

\section{Acknowledgments}

This project was funded by Academy of Sciences, Culture, Arts and African Diaspora (ASCAD, Côte d'Ivoire/Abidjan). The authors are gratefully for this support.

\section{References}

[1] FAO/IFAD/UNICEF/WFP/WHO, The State of Food Security and Nutrition in the World 2019. Safeguarding Against Economic Slowdowns and Downturns, Rome, (2019), 214p.

[2] UNICEF, Malnutrition: A Major Cause of Death in Children, retreivedhttps://reliefweb.int/report/world/malnutrit ion-major-cause-death-children, (2019), pp. 1-5. [3] Examen Stratégique National : «Faim ZÉRO », Côte d'Ivoire, 120 p, (2020).

[4] Association of Official Analytical Chemists (AOAC), Official methods of analysis, $16^{\text {th }}$ Edition, AOAC Inc ton, Washington DC, (1997).

Gisèle Ahou Yah KOUA, Konan Evrad Brice DIBI, Edwige Essoma AKOA, Sébastien NIAMKE, Development of enriched cupcakes and cookies with orange-fleshed sweet potato (Ipomea batatas L.): sensory and nutritional evaluation, Food and Environment Safety, Volume XX, Issue 2-2021, pag. 137 - 148 
[5] ALLEN L. H., Causes of Nutrition-related Public Health problems of Preschool Children: Available Diet, Journal of Pediatric Gastroenterology and Nutrition, 43: S8-S12, (2006).

[6] BOUIS H., J. LOW, MCEWAN M., TANUMIHARDJO S., Biofortification: Evidence and lessons learned linking agriculture and nutrition, FAO/WHO, pp. 1-23, (2013).

[7] NEELA S. FANTA S.W., Review on Nutritional Composition of Orange-Fleshed Sweet Potato and its Role in Management of Vitamin A Deficiency, Food Science \& Nutrition, March, pp. 1-24, (2019).

[8] LOW J.W., THIELE G., Understanding Innovation: The Development and Scaling of Orange-Fleshed Sweetpotato in Major African Food Systems, Agricultural Systems, 179: 102770, (2020).

[9] NIGUSSE G., T. HADERO, YOSEPH T. P., Evaluation of Nutritional, Microbial and Sensory Properties of Complementary Food Developed from Kocho, Orange-Fleshed Sweet Potato (Ipomoea batatas L.) and Haricot Bean (Phaseolus Vulgaris) for Under Five Years Children in Boricha Woreda, South Ethiopia, Journal of Food Processing, 85: 1-7, (2019).

[10] KOUA G., ZOUE T., MEGNANOU R.M., NIAMKE S., Nutritive Profile and Provitamin A Value of Sweet Potatoes Flours (Ipomoea batatas L.) Consumed in Côte d'Ivoire, Journal of Food Research, 7: 36-48, (2018).

[11] RIDLEY S. C., LIM M., HEENAN S., BREMER P., Evaluation of Sweet Potato Cultivars and Heating Methods for Control of Maltose Production, Viscosity and Sensory Quality, Journal of Food Quality, 28: 191-204, (2005).

[12] LARYEA D., WIREKO-MANU F. D., ODURO I., Formulation and Characterization of Sweetpotato-Based Complementary Food, Cogent Food Agriculture, 4: 1-15, (2018).

[13] HUFFMAN S. L., PIWOZ E. G, VOSTI S. A., DEWEY K. G., Babies, Soft Drinks and Snacks: A Concern in Low- and Middle-Income Countries? Maternal \& Child Nutrition, 10: 562574, (2014).

[14] MU T.-H., SUN H.-N., MA M.-M., Sweetpotato Snack Foods, Sweet Potato, Chemistry Processing and Nutrition, pp. 303-324, (2019).

[15] CHAUHAN A., SAXENA D. C., SINGH S., Physical, Textural, and Sensory Characteristics of Wheat and Amaranth Flour Blend Cookies. Cogent Food Agriculture, 2: 1125773, (2016).

[16] AOAC, Official Methods of Analysis of AOAC International, $19^{\text {th }}$ Edition, AOAC Internationnal, Gaithersburg, Maryland 20877-
2417, USA, (2012), 17 p.

[17] AFNOR, Compendium of French Standards, Fats, Oleaginous Grains, Derived Products. AFNOR Ed., Paris, (1986), 527 p.

[18] WOLF, Manual of Fat Analysis. Azoulay Edition, Paris, (1968), 519 p.

[19] FAO, Food Energy-Methods of Analysis and Conversion Factors. FAO Edition, Rome, (2002), 97 p.

[20] HOWE J. A. TANUMIHARDJO S. A., Carotenoid-Biofortified Maize Maintains Adequate Vitamin A Status in Mongolian Gerbils, Journal of Nutrition, 136: 2562-2567, (2006).

[21] Institute of Medicine, "Nutrients Summary" Dietary Reference Intake (RDIs): Vitamins, (2011), pp. 2-5.

[22] ISO 4833-1, Microbiology of the food chain - Horizontal method for the enumeration of microorganisms - Part 1: Colony count at $30^{\circ} \mathrm{C}$ by the pour plate technique, $1^{\text {st }}$ Edition, Genevia, (2013), 9p.

[23] ISO 21527-2, Microbiology of food and animal feeding stuffs - Horizontal method for the enumeration of yeasts and moulds - Part 2: Colony count technique in products with water activity less than or equal to 0,95, AFNOR, Saint-Denis (2008), $15 \mathrm{p}$.

[24] NF V08-061, Microbiology of food and animal fooding stuffs - Anaerobic Enumeration of sulfite-reducing bacteria by colony count technique at $46{ }^{\circ} \mathrm{C}, 1^{\text {st }}$ Edition, volume 33 , AFNOR, SaintDenis, (2009), 11p.

[25] NF ISO 4832, Microbiology of food and animal feeding stuffs - Horizontal method for the enumeration of coliforms - Colony-count technique, $1^{\text {st }}$ Edition, AFNOR, Saint-Denis, (2006), $10 \mathrm{p}$.

[26] ISO 6888-1, Microbilogy of food and animal feeding stuffs - Routine method for enumeration of coagulase positive Staphylococcus by colony-count technique at $37{ }^{\circ} \mathrm{C}$ - Part 1 : Technique with confirmation of the colonies, AFNOR, Saint-Denis, (1999), 15p.

[27] ISO 6579-1, Microbiology of food and animal feeding stuffs - Horizontal method for the detection of Salmonellaspp, AFNOR, Saint-Denis, (2002), 39p.

[28] XP V09-500. General guidelines for conducting hedonic tests in a sensory evaluation laboratory or in a controlled environment involving consumers, AFNOR, Paris, (2012), 30p

[29] HADERO T., Substitution of Sweet Potato (Ipomoea batatasL.) and Soybean (Glycine Max.) Flour with Durum Wheat (Triticum Durum) Flour Effect on Physicochemical and Sensory Characteristics of Cookies, Food Science and

Gisèle Ahou Yah KOUA, Konan Evrad Brice DIBI, Edwige Essoma AKOA, Sébastien NIAMKE, Development of enriched cupcakes and cookies with orange-fleshed sweet potato (Ipomea batatas L.): sensory and nutritional evaluation, Food and Environment Safety, Volume XX, Issue 2 - 2021, pag. 137 - 148 
Quality Management, 82: 22-29, (2019).

[30] KIDANE G., ABEGAZ K., MULUGETA A., SINGH P., Nutritional Analysis of Vitamin A Enriched Bread from Orange Flesh Sweet Potato and Locally Available Wheat Flours at Samre Woreda, Northern Ethiopia, Current Research in Nutrition and Food Science, 1: 49-57, (2013).

[31] WANG J., ROSELL C. M., BENEDITO DE BARBER C., Effect of the Addition of Different Fibres on Wheat Dough Performance and Bread Quality, Food Chemistry, 79: 221-226, (2002).

[32] NOVOTNI D., ĆURIĆ D., GALIĆ K., ŠKEVIN D., NEĐERAL S., KRALJIĆ K., GABRIĆ D., JEŽEK D., Influence of frozen storage and packaging on oxidative stability and texture of bread produced by different processes. LWT - Food Science and Technology, 44: 643-649, (2011).

[33] CAUVAIN S. P., CAKES: Nature of Cakes, Encyclopedia of Food Science and Nutrition (Second Edition), (2003), pp. 751-756.

[34] JEMZIYA M. B. F., MAHENDRAN T., Physical Quality Characters of Cookies Produced from Composite Blends of Wheat and Sweet Potato Flour, Ruhuna Journal of Science, 8: 12-23, (2017). [35] ANDUALEM A., KEBEDE A., ABADI G. M., Development of Pro-Vitamin A and Energy Rich Biscuits: Blending of Orange-Fleshed Sweet Potato (Ipomea batatas L.) With Wheat (Triticum vulgare) Flour and Altering Baking Temperature and Time, African Journal of Food Science, 10: 79-86, (2016).

[36] KOLAWOLE F. L., AKINWANDE B. A., ADE-OMOWAYE B. I. O., Physicochemical properties of novel cookies produced from orangefleshed sweet potato cookies enriched with sclerotium of edible mushroom (Pleurotustuberregium). Journal of the Saudi Society of Agricultural Science, 19: 174-178, (2018).
[37] NIRMALA PRASADI V. P., JOYE I. J., Dietary Fibre from Whole Grains and Their Benefits on Metabolic Health, Nutrients, 12: 1-20, (2020).

[38] REIßNER A.-M., BEER A., STRUCK S., ROHM H., Pre-Hydrated Berry Pomace in Wheat Bread: An Approach Considering Requisite Water in Fiber Enrichment, Foods, 9: 1600, (2020).

[39] OKORIE S. U., ONYENEKE E.N., Production and Quality Evaluation of Baked Cake from Blend of Sweet Potatoes and Wheat flour, Academic Research International, 3: 171-177, (2012).

[40] TEFERRA T. F., KURABACHEW H., TADESSE T. F., NIGUSSE G., Nutritional, Microbial and Sensory Properties of Flat-bread (kitta) Prepared from Blends of Maize (Zea mays L.) and Orange-fleshed Sweet Potato (Ipomoea batatas L.) Flours. Int. J. Food Sci. Nutr. Eng., 5: 33-39, (2015).

[41] KORESE J. K., CHIKPAH S. K, HENSEL O., PAWELZIK E., STURM B., Effect of Orange-Fleshed Sweet Potato Flour Particle Size and Degree of Wheat Flour Substitution on Physical, Nutritional, Textural and Sensory Properties of Cookies. European Food Research and Technology, 247: 889-905, (2021).

[42] CHIKPAH S. K., KORESE J. K., HENSEL O., STURM B., Effect of Sieve Particle Size and Blend Proportion on the Quality Properties of Peeled and Unpeeled Orange Fleshed Sweet Potato Composite Flours, Foods, 9: 740, (2020).

[43] SHARIF M. K., BUTT M. S., SHARIF H. R., NASSIR M., Sensory Evaluation and Consumer Acceptability, Chapter 14, (2017), pp. 361-386.

[44] SABANIS D., TZIA C., Effect of Rice, Corn and Soy Flour Addition on Characteristics of Bread Produced from Different Wheat Cultivars, Food Bioprocess Technology, 2: 68-79, (2009)

Gisèle Ahou Yah KOUA, Konan Evrad Brice DIBI, Edwige Essoma AKOA, Sébastien NIAMKE, Development of enriched cupcakes and cookies with orange-fleshed sweet potato (Ipomea batatas L.): sensory and nutritional evaluation, Food and Environment Safety, Volume XX, Issue 2-2021, pag. 137 - 148 